\title{
Campaign Simulation for American Government: An Active Learning Approach to Campaigns and Elections
}

Gayle Alberda, Fairfield University

ABSTRACT Instructors of American government are challenged with teaching students from a variety of disciplines. Utilizing active learning methods captures students in a manner traditional lectures cannot. For this study I employed an experimental design to assess a campaign simulation used in an Introduction to American Government course. Results show the simulation aided in students' learning about campaigns and elections.

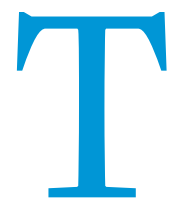
eaching an introductory course of American government can challenge instructors. This course is generally comprised of students from across disciplines. The difficulty lies in creating a course that engages students from these various disciplines.

A common strategy used by instructors to engage students is through active learning approaches which involve students in "higher-order thinking tasks as analysis, synthesis and evaluation" (Bonwell and Eison 1991, 5). "Active learning involves students in doing things and thinking about the things they are doing" (Bonwell 2000, 2). Active learning strategies include simulations, role playing, and group participation, just to name a few.

In political science courses, a frequent active learning method involves simulations, which is a way to mimic a realworld situation in the classroom. Some of the role-playing simulations used by political science professors include a mock constitutional convention (Pautz 2011), a ten-week political campaign (Kathlene and Choate 1999), and a mock Congress (Baranowski 2006).

Using simulations in an American government course provides many benefits. It gives students with different learning styles a chance to flourish (Newmann and Twig 2000), and encourages student participation (Smith and Boyer 1996). In an assessment of a campaign simulation used in an Introduction to American Government class, Pappas and Peaden (2004) asked students if the simulation made them feel more interested in politics. On a response scale from 1 (strongly agree) to 4 (strongly disagree) the mean response was 2.10 for the Introduction to American Government class and 1.37 for an upper-level political science course. Similarly, Caruson (2005) found that $97.6 \%$ of students indicated that the campaign exercise caused them to become more interested in the election process. Other studies have demonstrated that simulations in political science courses promote interest

Gayle Alberda is an assistant professor in the political science department at Fairfield University. She can be reached at galberda@gmail.com. in the subject matter (Caruson 2005; Pappas and Peaden 2004) and give students a positive learning experience (Caruson 2005; Endersby and Webber 1995; McCarthy and Anderson 2000; Pautz 2011).

I developed a mock campaign budget activity for my Introduction to American Government class. The simulation incorporates concepts learned from the chapters on campaigns and elections with materials from chapters on political participation and political parties. By creating a campaign budget, students have to make strategic decisions on how to spend campaign funds, what groups of voters to target, when to conduct an absentee chase program and/or voter registration drive, how to mobilize voters, and how to design messaging. The choices they make during the 12-week campaign are linked to a predetermined vote total. This connects their decisions to voter turnout in a way a traditional lecture cannot. A large component to this activity is the timing of their decisions. For instance, organizing a voter registration drive the last week of the campaign (i.e., right before Election Day) does not yield the same number of votes as it would earlier in the campaign (i.e., before the registration deadline). As with most simulations, the overall goal is to help students marry the course materials with a real-world application and to engage them to critically think about the course materials and apply them to the activity. Other goals include fostering their political interest.

This campaign simulation study differs from previous research in a variety of ways. First, I taught two sections of American Government, which allowed me to have a treatment group (who participated in the activity) and a control group (who did not participate in the activity). Most of the previous studies using campaign simulations have only reported on the participants in their activity (see Caruson 2005; Kathlene and Choate 1999; Pappas and Peaden 2004). By teaching two courses during the same semester, I was able to empirically test if the two classes differed on key components of active learning, such as an increase in political interest. Second, my campaign simulation is shorter in 
length and can be done within one or two class periods. Barriers to classroom simulations include having enough time to cover additional material in the course and large class sizes (Bonwell $2000,4)$. A short simulation allows the instructor to engage in active learning without losing valuable class time dedicated to other areas. Third, it focuses the students' attention on the details of determining a campaign budget and how those choices impact voter turnout. Fourth, it includes other actors in an election that could impact voter turnout, such as super PACs and 527 organizations. Finally, students are confronted with making strategic decisions for their campaign, such as which types of voters to target and when. This simulation provides the students with the means to gain a deeper understanding of how actors in elections and decisions campaigns make impact the results on Election Day.

Since I was teaching two classes of American government, I utilized this opportunity to conduct an experiment with the simulation. I randomly selected one class to participate in the simulation (i.e., the treatment group); the activity was placed on the syllabus after the chapters on political participation, political parties, and campaigns and elections were covered. The other class had the same syllabus without the simulation activity on it. The treatment group had class on Monday and Wednesday while the control group had class on Tuesday and Thursday. Both classes covered the same materials, had the same textbooks, and had the same lectures. Exams were not the same due to academic integrity; however, the exams for both classes covered the same chapters, concepts, and materials, just with different questions. I administered the same follow-up survey instrument to both groups, but the treatment group was asked supplementary questions about the simulation. The treatment group responded to the survey after participating in the activity while the control group responded after the lecture on campaigns and elections (this was the last lecture on the three topics the simulation covers).
In larger classes, there may be four groups or more (see Appendix A). The teams face off for a 12-week general election race for the US Senate. Each team is assigned a mock US Senate district. The information on the Senate districts includes current issues, demographics of population and voters, details about voter registration deadlines, information on industries, as well as other general items (see Appendix B). On each team, one student is assigned the position of candidate while the other students are campaign staff. When working on the campaign budget, if there is a tie vote on something the candidate has the final say. Each team is given a campaign budget form and a list of items they can purchase for their campaign (e.g., mailings, ads, and buttons). Each item has a specified dollar amount attached to it (see Appendix C). They can distribute their funds how they see fit. Their goal is to apply the course material in such a way that they gain the most votes and win on Election Day.

Students spend the first class period (75 minutes) deciding what items to purchase for each week in the budget and record these on the Campaign Budget Sheet (see Appendix D). The only requirement is that they must have a headquarters and a campaign manager the last week of the campaign. As a group, they determine the following: which campaign items to purchase; how much of each item to purchase; when to purchase each item; what type of voters the items will target; whether or not to take PAC money, hold a fundraiser, or have a surrogate speak on their behalf. For instance, if they purchase district-wide mailers, they would need to not only specify the weeks they will be purchasing them, but also how much they will be purchasing, what type of message they will be sending on those mailers, and which groups of voters they will be mailing to. If they take PAC money, hold a fundraiser, or have a surrogate speak, they can increase their campaign budget by various amounts. I have note cards with predetermined amounts written on them that represent income from fundraising, except for PAC money. The groups randomly draw these amounts, which they would then add to their budgets making sure to abide by

\section{I randomly selected one class to participate in the simulation (i.e., the treatment group); the activity was placed on the syllabus after the chapters on political participation, political parties, and campaigns and elections were covered. The other class had the same syllabus without the simulation activity on it.}

The treatment group engaged in the mock campaign budget activity after they read, and I lectured on, the topics of political participation, campaigns and elections, and political parties. Generally, this activity takes two class periods. The first class period is dedicated to the students working as a team on the budget. During the second class period, more time can be given to working on the budget if necessary. However, it is primarily used for calculating vote totals based on their budget plans. The goal of the campaign budget simulation is for students to think critically about campaigns and voters, as well as how political organizations impact the success or failure of a campaign. With any campaign there are a myriad of dynamics occurring simultaneously. This activity attempts to incorporate many of these dynamics.

During the activity, students are randomly divided into a Republican candidate campaign team or a Democrat candidate campaign team. I generally assign four to five students to a group. campaign finance laws. At the same time, they know Super PACS and 527 organizations are also conducting activities during the election. However, since they are legally barred from coordinating with them, they do not know what exactly these other political organizations are doing on behalf of their campaign.

During the second class period (also 75 minutes), I give students a few minutes to regroup and make any adjustments to their budgets, then we calculate votes. This is our mock Election Day. A sheet lists the number of votes earned or lost based on each item purchased during the 12-week schedule (see Appendix E). A few items are awarded more votes if they are purchased during optimal weeks in the campaign. For example, a group sending out absentee ballots during the last week of the election would lose votes (subtracted from the total), because for their district, absentee voting has ended. But, sending out absentee ballots during earlier weeks would earn votes since that is the optimal time to 
chase absentee ballots. Therefore, groups who pay attention to the timing of campaign activities will typically garnish more votes.

While calculating their vote totals, groups report what voters they targeted in their campaign and why. Groups who target their party's base are awarded votes while groups who do not are awarded no votes or lose votes. For instance, if the Republican team targeted unions, they would lose votes. The Super PAC and 527 activities are revealed and votes are added or subtracted based on these activities. This aspect of the activity helped students understand how political parties work with candidates, campaigns, and elections.
A goal was to connect the course materials to a real-life application. Based on student feedback, it appears that this simulation helped achieve this goal. Students frequently commented that the simulation allowed them to apply theory to real life: "[It] lets you apply the information learned in class in a real way"; "I was also surprised at how we were able to connect everything we have learned this semester to the activity. It forced us all to think deeper about multiple political aspects and how they work together and connect"; "You were able to immerse yourself in a similar situation that every politician goes through. It is one thing to read a book and understand the concept, but to put the

\section{Groups who target their party's base are awarded votes while groups who do not are awarded no votes or lose votes. For instance, if the Republican team targeted unions, they would lose votes.}

After the activity, students received a survey to empirically measure the students' reactions to the simulation. The questions on this survey have been used by previous scholars (see Endersby and Webber 1995; Pappas and Peaden 2004). There were 26 students in the class that served as the treatment group. Of the 26 students in the class, 24 answered the survey: a response rate of $92 \%$. In the class that served as the control group, there were 28 students, of whom 25 answered the survey: a response rate of $89 \%$.

Overall, the feedback from the treatment group was positive. Many of the students indicated they enjoyed the simulation. One student wrote, "I was surprised at how much I enjoyed it and how involved I got." Others indicated: "It was fun"; "I enjoyed the activity"; and "It was fun to get involved and do something." When asked to rate how enjoyable the simulation was on a scale of 1 (strongly disagree) to 5 (strongly agree), students in the treatment group had a mean score of 4.5 . Table 1 summarizes all the results of the survey.

Likewise, when students were asked whether the simulation got them more involved in the class, on a scale of 1 (strongly disagree) to 5 (strongly agree) the mean score was 4.6. Students seemed to enjoy the activity and become more involved as a result of participating. Some students indicated that the best part of the activity was collaborating: "The best thing was getting to work through issues as a group and deciding together how best to run this campaign"; "Getting to collaborate in a group setting and strategizing and how to best spend money and campaign." understanding into action really gives a deeper knowledge of the content"; "The campaign activity was good insight [into] what politicians do to receive votes"; "The best part was that it was realistic"; "It made me apply what we learned in class by using it to create all aspects of the campaign." When students were asked if the simulation was a useful learning tool, on a scale of 1 to 5 the mean score was 4.3. Similarly, for how the simulation helped students learn more about campaigns and elections the mean score for responses was 4.5 . Over $95 \%$ of students indicated the simulation should be offered in future classes.

Engaging students in a manner that fosters their interest in politics was another goal of the simulation. A few students made comments indicating it spurred their interest. Both the treatment and control group were asked about their political interest. On a scale of 1 (little political interest) to 3 (strong political interest), the mean for political interest in the treatment group was 2.3 and 2.0 in the control group, although the difference is not statistically significant, $t(1.657), d f=43.944, p=.105$. This is not surprising as many of the students in both classes are already politically active: $71 \%$ of students in the treatment group and $72 \%$ of students in the control group indicated they were registered voters. Of those registered, $50 \%$ of students in the treatment group and $40 \%$ of students in the control group voted in the 2014 election. Both groups had a median age of 19 (table 2.) Only one-third of young adults vote in presidential elections and less than one-fifth in congressional elections (Galston 2004). Students in both of

\section{Table 1}

Students' Reactions to Campaign Budget Activity

\begin{tabular}{lccccccc} 
& N & Mean & $\begin{array}{c}\text { Percent Strongly } \\
\text { Agree (5) }\end{array}$ & $\begin{array}{c}\text { Percent } \\
\text { Agree (4) }\end{array}$ & $\begin{array}{c}\text { Percent } \\
\text { Neutral (3) }\end{array}$ & $\begin{array}{c}\text { Percent } \\
\text { Disagree (2) }\end{array}$ & $\begin{array}{c}\text { Percent Strongly } \\
\text { Disagree (1) }\end{array}$ \\
\hline Simulation was useful & 24 & 4.3 & 33.3 & 62.5 & 4.2 & 0 & 0 \\
\hline Simulation was enjoyable & 24 & 4.5 & 54.2 & 45.8 & 0 & 0 & 0 \\
\hline Simulation helped me learn more about campaigns and elections & 24 & 4.5 & 54.2 & 37.5 & 8.3 & 0 & 0 \\
\hline Simulation caused me to be more involved in the class & 24 & 4.7 & 66.7 & 33.3 & 0 & 0 \\
\hline Simulation should be offered in future classes & 24 & 4.7 & 75 & 20.8 & 4.2 & 0 & 0 \\
\hline Note: Results are rounded to the nearest tenth & & & & & &
\end{tabular}


Table 2

Classroom Demographics

\begin{tabular}{lccccccc} 
& $\boldsymbol{n}$ & $\begin{array}{c}\text { Number of Political Science } \\
\text { Courses* Mean (Median) }\end{array}$ & $\begin{array}{c}\text { Year in College } \\
\text { Mean (Median) }\end{array}$ & $\begin{array}{c}\text { Age Mean } \\
\text { (Median) }\end{array}$ & Female \% & $\begin{array}{c}\text { Registered to } \\
\text { Vote \% }\end{array}$ & $\begin{array}{c}\text { Voted in 2014 } \\
\text { General Election \% }\end{array}$ \\
\hline Treatment Group & 24 & $.21(.00)$ & $1.42(1.00)$ & $18.91(19.00)$ & 71 & 71 & 50 \\
\hline Control Group & 25 & $.92(.00)$ & $1.84(1.00)$ & $17.32(19.00)$ & 56 & 72 & 40 \\
\hline
\end{tabular}

Notes: Results are rounded. * Does not include the Introduction to American Government course.

my classes self-reported higher rates of voting than most young adults. Given the 2014 general election occurred before this study was conducted, it could be that students in both groups are likely more engaged than most in their cohort.

While this simulation was designed for an introduction course on American government, it could be adapted to other courses, such as state and local government or American electoral processes. In their feedback, students indicated that only two days for the simulation was not enough. They would have enjoyed more time to work on their budget strategy. Others suggested that it would have been nice to select their own political party versus being randomly assigned.

Active learning methods reach students in a manner traditional lectures cannot. Many students report becoming more knowledgeable, having a better understanding of the process, and enjoying the simulation activity (Ciliotta-Rubery and Levy 2000; Endersby and Webber 1995; Kathlene and Choate 1999; Pautz 2011). This simulation produced similar results. One student summed it up nicely: "It was interactive and I was actively involved in my learning process instead of just listening. It was also fun to interact with my peers." This simulation helped students to better understand the relationship between voters, political parties, and campaigns during an election cycle. It provided students with an opportunity to engage with each other, gain insight into the complexity of elections, and develop their critical thinking skills. On Election Day, students were able to see how their choices related to voters and how their hard work paid off. Students really enjoyed this aspect of the simulation, especially the election winners.

\section{SUPPLEMENTARY MATERIAL}

To view supplementary material for this article, please visit http://dx.doi.org/10.1017/S1049096516001566.*

\section{REFERENCES}

Baranowski, Michael. 2006. "Single Session Simulations: The Effectiveness of Short Congressional Simulations in Introductory American Government Classes." Journal of Political Science Education 2 (1): 33-49.

Bonwell, Charles C. 200o. Active Learning: Creating Excitement in the Classroom. Green Mountain Falls, CO: Active Learning Workshops. https://www.ydae. purdue.edu/lct/HBCU/documents/Active_Learning_Creating_Excitement in_the_Classroom.pdf

Bonwell, Charles C. and James A. Eison. 1991. Active Learning: Creating Excitement in the Classroom. ASHE-ERIC Higher Education Report No.1. Washington, DC: George Washington University, School of Education and Human Development.

Caruson, Kiki. 2005. "So, You want to Run for Elected Office? How to Engage Students in the Campaign Process without Leaving the Classroom." PS: Political Science \& Politics 38 (2): 305-10.

Ciliotta-Rubery, Andrea and Dena Levy. 200o. "Congressional Committee Simulation: An Active Learning Activity.” PS: Political Science \& Politics 33 (4): $847-51$.

Endersby, James W. and David J. Webber. 1995. "Iron Triangle Simulation: A Role-Playing Game for Undergraduates in Congress, Interest Groups, and Public Policy Classes." PS: Political Science \& Politics 28 (3): 520-23.

Galston, William A. 2004. "Civic Education and Political Participation.” PS: Political Science and Politics 37 (2): 263-66

Kathlene, Lyn and Judd Choate. 1999. "Running for Elected Office: A Ten-Week Political Campaign Simulation for Upper-Division Courses." PS: Political Science \& Politics 32 (1): 69-76.

McCarthy, J. Patrick and Liam Anderson. 200o. "Active Learning Techniques versus Traditional Teaching Styles: Two Experiments from History and Political Science." Innovative Higher Education 24 (4): 279-94.

Newmann, William W. and Judyth L. Twigg. 200o. "Active Engagement of the Intro IR Student: A Simulation Approach." PS: Political Science \& Politics 33 (4): 835-42.

Pappas, Christine and Charles Peaden. 2004. "Running for Your Grade: A Six-Week Senatorial Campaign Simulation." PS: Political Science \& Politics 37 (4): 859-63.

Pautz, Michelle C. 2011. "Challenging the Constitution: Convening a Mock Constitutional Convention for American Government Students.” PS: Political Science \& Politics. 44 (3): 648-51.

Smith, Elizabeth T. and Mark A. Boyer. 1996. "Designing In-Class Simulations.” PS: Political Science \& Politics 29 (4): 690-94.

* The URL to access Supplementary Material for this article has been corrected since the original publication. An Erratum detailing this change was also published (DOI: 10.1017/S1049096516002481). 